[Original]

\title{
Glutathione S-Transferase (GST) M1, T1, P1, $N$-Acetyltrans- ferase (NAT) 1 and 2 Genetic Polymorphisms and Suscep- tibility to Colorectal Cancer
}

\author{
Makoto YoshIOKA ${ }^{1}$, Takahiko KATOH ${ }^{1}$, Masahiro NAKANO ${ }^{1}$, Shin TAKASAWA ${ }^{2}$, \\ Naoki NAGATA ${ }^{2}$ and Hideaki ITOH ${ }^{2}$ \\ ${ }^{1}$ Department of Health Information Science, School of Health Sciences, University of Occupational and \\ Environmental Health, Japan. Yahatanishi-ku, Kitakyushu 807-8555, Japan \\ ${ }^{2}$ Department of Surgery I, School of Medicine, University of Occupational and Environmental Health, \\ Japan. Yahatanishi-ku, Kitakyushu 807-8555, Japan
}

Abstract: A case-control study was carried out to examine the relation between genetic polymorphisms of five genes, cigarette smoking and colorectal cancer risk. We collected blood samples from 106 colorectal cancer patients and 100 healthy persons, then analyzed them to identify genotypes for glutathione S-transferase (GST) M1, T1, P1, $N$-acetyltransferase (NAT) 1 and 2 by the PCR method. We also collected smoking history data from all participants by questionnaire. From statistical evaluation on various combinations of genotypes, we observed that the cancer risk of those who have both GSTM1 present genotype and GSTP1 Adenine/Adenine homozygous genotype was significantly less than those who have other combinations of genotypes for two genes. For other combinations of genes, there was no significant association between genotype and cancer risk. There was also no significant association between amount of cigarette smoking and the cancer risk. These findings suggest that it is valuable to study cancer risk when examining genotypes of more than two genes at the same time. For further study, we need to collect more samples to increase statistical reliability, and besides cigarette smoking, include the nutrition data as an environmental factor.

Key words:colorectal cancer, genetic polymorphism, GST, NAT, cigarette smoking.

(Received 17 August 1998, accepted 5 March 1999)

\section{Introduction}

The risk of cancer is associated with various types of exposures and host factors, including differences in carcinogen metabolism. Enzymatic activation and deactivation of carcinogens is a major principle in chemical carcinogenesis as host factor $[1,2]$. Epidemiological studies contribute to understanding the xenobiotic metabolism of carcinogenesis in 
humans. This type of analysis is especially suitable for those enzymes that are polymorphically expressed on a heritable basis [3-5], enabling a comparison of cancer risks among subjects with genetically deficient or an extremely active metabolism to risks among those with normal activity.

Recently, the genetic basis of polymorphic activities of glutathione S-transferase M1 (GSTM1), glutathione S-transferase T1 (GSTT1), glutathione S-transferase P1 (GSTP1), $N$-acetyltransferase 1 (NAT1), and $N$-acetyltransferase 2 (NAT2) have been largely elucidated $[6-10]$. Biological data suggest that these enzymes may be involved in carcinogenesis, and that polymorphism of the enzymes affects the susceptibility of various types of cancer.

The polymorphic GST's catalyze the conjugation of glutathione to a variety of electrophilic compounds, including carcinogens and cytotoxic drugs $[11,12]$. Absence of GSTM1 activity, a $\mu$ class enzyme, which detoxifies the reactive metabolites of benzo [a]pyrene and other polycyclic aromatic hydrocarbons [13], is due to homozygous deletion of the gene

[6]. A similar polymorphism of the GSTT1 gene, encoding $\theta$ class enzymes, was recently discovered [7]. GSTT1 metabolizes various potential carcinogens such as monohalomethanes that are widely used as methylating agents, pesticides and solvents [14]. Recently a polymorphic site at nucleotide 313 (an adenine to guanine substitution replacing isoleucine with valine) in the GSTP1 gene which encodes $\pi$ class enzymes, was detected and found to modify the enzyme's specific activity and affinity for electrophilic substrates $[8$, 15]. GSTP1 is widely expressed in normal epithelial tissue, particularly abundant in the urinary, respiratory and digestive tracts [16].

Epidemiological studies have shown that a phenotype of low activity of NAT2 is associated with an increased risk of urothelial cancer among occupationally exposed dye workers

[17]. The genetic alteration underlying the NAT2 polymorphisms has been determined and corrected with NAT2 enzyme activities. The four major NAT2 alleles in Japanese are represented by the wild-type allele $(\mathrm{NAT} 2 * 4)$ and three low activity alleles (NAT2 ${ }^{*} 5, \mathrm{NAT} 2{ }^{*}$ 6 and NAT2*7). A homozygous low activity allele genotype produces a slow acetylator phenotype. Though the NAT1 gene has only been recently shown to be polymorphic and has not received as much attention as NAT2, several pilot studies have been reported for some kinds of cancer $[18-20]$.

Cigarette smoking is one of the important environmental risk factors for cancer development [21]. Many carcinogenic compounds including benzo[a]pyrene and arylamines are present in cigarette smoke. These chemicals are substrates of GSTM1, GSTT1, GSTP1, NAT1 and NAT2 $[22,23]$. Several epidemiological studies have been performed on the relation between cigarette smoking and colorectal cancer risk [24-26]. Recently, some studies tried to examine the association between a few genotypes and colorectal cancer [27$31]$ and a few studies investigated the interaction between a few genotypes, cigarette smoking and colorectal cancer risk [32]. The main purpose of this paper is to elucidate the relation- 
ship between the genotypes of five enzymes, cigarette smoking, and the susceptibility of colorectal cancer by the case-control study.

\section{Subjects and Methods}

Subjects : Blood samples were taken from 106 patients with colorectal cancer (C18 and C19 in ICD10 classification) and 100 healthy controls who have never suffered from any type of cancer. The colorectal cancer group comprised 69 males and 37 females and the mean and standard deviation of age was 62.3 years and 12.0 respectively. They were consecutive cases at the University of Occupational and Environmental Health Hospital, Mitsubishi Chemical Hospital and Kitakyushu Medical Center, and had been histologically diagnosed from September 1991 to June 1995. Patients sampling was purely sequential in this period and no intentional selection was done for sampling. The control group consisted of 58 males and 42 females who had visited local medical clinics in Kitakyushu City between September 1993 and April 1995 for regular medical health check-ups including the collection of blood and urine specimens. The mean age was 61.7 years and the standard deviation was 16.0. No intentional sampling selection was done for the control group except for excluding a person who had a history of cancer. Though no specific age matching was carried out, there was no significant difference in the mean value between cases and controls $(t$ and $P$ value of Student's $t$-test for mean difference was 0.30 and 0.81 respectively).

All participants were interviewed regarding medical, residential and smoking history. Their smoking history was summarized as the total amount of cigarettes smoked during their lifetime up until the time of interview, taking into account changes in smoking habit with age. The amount of cigarette smoke exposure was assessed by pack-year (pack/day $\times$ years of smoking). All participants were given an explanation of the nature of the study and informed consent was obtained.

Genotyping : In order to identify the genotype of the GSTM1, GSTT1, GSTP1, NAT1 and NAT2, the polymerase chain reaction (PCR) method was used $[9,15,33]$. Genotypes and grouping of genotypes that we used in this paper are shown in Table 1. For GSTM1 and GSTT1, we classified two genotypes; present and null (deleted) genotype. For GSTP1, we classified three genotypes and called them $A / A, A / G$ and $G / G$ genotype in this paper. A/A genotype means Adenine/Adenine homozygous at nucleotide 313. A/G means Adenine/Guanine heterozygous, while G/G means Guanine/Guanine homozygous at nucleotide 313. When we called GSTP1 with $G$ genotype, it referred to both $A / G$ and $G / G$. For NAT1, we classified three genotypes and called them ${ }^{*} 4 /{ }^{*} 4,{ }^{*} 4 /{ }^{*} 10$ and ${ }^{*} 10 /{ }^{*} 10 .{ }^{*} 4 /{ }^{*} 4$ genotype means $\mathrm{NAT} 1{ }^{*} 4$ homozygous genotype composed of $\mathrm{NAT} 1{ }^{*} 4 / \mathrm{NAT}^{*} 4$ allele pair. ${ }^{*} 4 /{ }^{*} 10$ genotype means heterozygous mutant genotype composed of NAT1 ${ }^{*} 4 / \mathrm{NAT}^{*} 10$ allele pair, while ${ }^{*} 10 /{ }^{*} 10$ means homozygous mutant genotype composed of NAT $1{ }^{*} 10 /$ $\mathrm{NAT}^{*} 10$ allele pair. Other genotypes, for example, NAT $1{ }^{*} 3$ and NAT $1 * 11$, are neglected 
Table 1. Genotypes and their allele pair composition for five genes.

Groupings of genotype for three genes are depicted by parentheses

\begin{tabular}{|c|c|c|}
\hline Gene & Genotype & allele pair composition \\
\hline \multirow{2}{*}{ GSTM1 } & Present & present/present or present/deleted \\
\hline & Null & deleted/deleted \\
\hline \multirow{2}{*}{ GSTT1 } & Present & present/present or present/deleted \\
\hline & Null & deleted/deleted \\
\hline \multirow{3}{*}{ GSTP1 } & \multirow{3}{*}{$\sqrt{-}$ (with $\mathrm{G})$} & Adenine/Adenine at nucleotide 313 \\
\hline & & Adenine/Guanine at nucleotide 313 \\
\hline & & Guanine/Guanine at nucleotide 313 \\
\hline \multirow{3}{*}{ NAT1 } & \multirow{3}{*}{$\neg($ with $* 10)$} & NAT $1 * 4 / \mathrm{NAT}^{*} * 4$ \\
\hline & & NAT $1 * 4 / \mathrm{NAT} 1 * 10$ \\
\hline & & NAT $1 * 10 / \mathrm{NAT} 1 * 10$ \\
\hline \multirow{3}{*}{ NAT2 } & \multirow{3}{*}{$\neg-($ Rapid/Intermediate $)$} & $\mathrm{NAT} 2 * 4 / \mathrm{NAT} 2 * 4$ \\
\hline & & NAT2 $* 4$ /other type allele ${ }^{1)}$ \\
\hline & & other type allele /other type allele \\
\hline
\end{tabular}

1) $\mathrm{NAT}_{2} * 5, \mathrm{NAT} 2 * 6, \mathrm{NAT} 2 * 7$

in this study, because there is very little possibility of them in the Japanese. For NAT2, we classified three categories and we called them rapid, intermediate and slow genotype. Rapid genotype means NAT2 ${ }^{*} 4$ homozygous genotype composed of NAT2 ${ }^{*} 4$ /NAT2 ${ }^{*} 4$ allele pair. Intermediate genotype means heterozygous genotype composed of NAT2 ${ }^{*} 4$ and other types of NAT2 mutant allele; NAT2 ${ }^{*} 5$, NAT2 ${ }^{*} 6$, NAT2 ${ }^{*} 7$, while slow genotype means homozygous mutant genotype.

Statistical analysis : First, the relation between the genotype and the risk of colorectal cancer was examined for each gene by chi-square tests and odds ratio evaluations. Secondly, the same statistical analysis was done for various combinations of genotypes of two different genes. Thirdly, the association of amount of cigarette smoking and the risk of cancer was examined by chi-square tests.

\section{Results}

Genotypes and cancer risk : In order to elucidate the relation between the genotype and the susceptibility of colorectal cancer, we did chi-square tests and calculated the odds ratio which indicates the relative risk. Table 2 shows frequency tables of control and cases classified by genotype for each gene with the results of chi-square tests and odds ratio evaluations. For GSTM1 and GSTT1, the frequency tables are $2 \times 2$. For GSTP1, NAT1 and NAT2, the frequency tables are $3 \times 2$, because these genes have 3 genotypes. However, these genotypes can be classified into two categories according to their effect on carcinogen metabolism. For GSTP1, A/G and G/G genotypes were classified under the same category, and we called 
Table 2. Frequency tables of control and case classified by categories of genotype for each gene with $\chi^{2}$ value and odds ratio

\begin{tabular}{lccccc} 
GSTMI & & & \\
\hline Genotype & Control & Case & $\chi^{2}$ & $P$ & Odds ratio $(95 \% \mathrm{CI})$ \\
\hline Present $^{\dagger}$ & 58 & 50 & 2.42 & 0.12 & $1.55(0.89-2.68)$ \\
Null & 42 & 56 & & & \\
\hline
\end{tabular}

GSTT1

\begin{tabular}{lccccc}
\hline Genotype & Control & Case & $\chi^{2}$ & $P$ & Odds ratio $(95 \% \mathrm{CI})$ \\
\hline Present $^{\dagger}$ & 59 & 55 & 1.05 & 0.31 & $1.33(0.77-2.32)$ \\
Null & 41 & 51 & & & \\
\hline
\end{tabular}

\section{GSTP1}

\begin{tabular}{lccccc}
\hline Genotype & Control & Case & $\chi^{2}$ & $P$ & Odds ratio (95\% CI) \\
\hline $\mathrm{A} / \mathrm{A}$ & 76 & 72 & & & \\
$\mathrm{~A} / \mathrm{G}$ & 21 & 34 & not reliable & & \\
$\mathrm{G} / \mathrm{G}$ & 3 & 0 & & & \\
\hline $\mathrm{A} / \mathrm{A}^{\dagger}$ & 76 & 72 & $1.50(0.81-2.76)$ \\
With $\mathrm{G}$ & 24 & 34 & 1.66 & 0.20 & 1.00 \\
\hline
\end{tabular}

NAT1

\begin{tabular}{lccccc}
\hline Genotype & Control & Case & $\chi^{2}$ & $P$ & Odds ratio $(95 \% \mathrm{CI})$ \\
\hline$* 4 / * 4$ & 36 & 38 & & & \\
$* 4 / * 10$ & 42 & 42 & 0.21 & 0.90 & \\
$* 10 / * 10$ & 22 & 26 & & & \\
\hline$* 4 * 4$ & 36 & 38 & & & \\
With $* 10$ & 64 & 68 & 0.001 & 0.98 & $(0.57-1.78)$ \\
\hline
\end{tabular}

NAT2

\begin{tabular}{lccccc}
\hline Genotype & Control & Case & $\chi^{2}$ & $P$ & Odds ratio (95\% CI) \\
\hline Rapid & 49 & 60 & & & \\
Intermediate & 44 & 41 & 1.38 & 0.50 & \\
Slow & 7 & 5 & & & \\
\hline Rapid/Intermediate & 93 & 101 & $0.66(0.20-2.14)$ \\
Slow & 7 & 5 & 0.16 & 0.69 & 0.69 \\
\hline
\end{tabular}

(note : Affixed maker ${ }^{\dagger}$ indicates reference group for odds ratio calculation.)

it GSTP1 with G genotype. For NAT1, ${ }^{*} 4 /{ }^{*} 10$ and $* 10 /{ }^{*} 10$ genotypes were classified under the same category, and we called it NAT1 with*10. For NAT2, rapid and intermediate genotypes were classified as the same category, and we named it rapid/intermediate (See Table 1 for these grouping). There are also $2 \times 2$ frequency tables for these genes using the above groupings in Table 2 . 
Table 3. Frequency tables of control and case classified by categories of combination of each genotype with $\chi^{2}$ value and odds ratio

GSTMI and GSTTI

\begin{tabular}{ccccccc}
\hline \multicolumn{2}{c}{ Genotype } & Control & Case & $\chi^{2}$ & $P$ & Odds ratio (95\%CI) \\
GSTM1 & GSTT1 & & & & \\
\hline Present & Present & 36 & 30 & & \\
Present & Null & 22 & 20 & 3.43 & 0.33 & \\
Null & Present & 23 & 25 & & & \\
Null & Null & 19 & 31 & & & \\
\hline Present & Present $^{\dagger}$ & 36 & 30 & 3.12 & 0.08 & $1.92(0.93-4.12)$ \\
Null & Null & 19 & 31 & & & \\
\hline
\end{tabular}

GSTMI and GSTPI

\begin{tabular}{|c|c|c|c|c|c|c|}
\hline \multicolumn{2}{|c|}{ Genotype } & \multirow[t]{2}{*}{ Control } & \multirow[t]{2}{*}{ Case } & \multirow[t]{2}{*}{$\chi^{2}$} & \multirow[t]{2}{*}{$P$} & \multirow[t]{2}{*}{ Odds ratio $(95 \% \mathrm{CI})$} \\
\hline GSTM1 & GSTP1 & & & & & \\
\hline Present & $\mathrm{A} / \mathrm{A}$ & 47 & 31 & \multirow{4}{*}{7.45} & \multirow{4}{*}{0.0589} & \\
\hline Present & with $\mathrm{G}$ & 11 & 19 & & & \\
\hline Null & $\mathrm{A} / \mathrm{A}$ & 29 & 41 & & & \\
\hline Null & with $\mathrm{G}$ & 13 & 15 & & & \\
\hline Present & $\mathrm{A} / \mathrm{A}^{+}$ & 47 & 31 & \multirow{2}{*}{6.89} & \multirow{2}{*}{0.0086} & \multirow{2}{*}{$2.15(1.21-3.79)$} \\
\hline Other $\mathrm{c}$ & hation & 53 & 75 & & & \\
\hline
\end{tabular}

\section{GSTT1 and GSTPl}

\begin{tabular}{ccccccc}
\hline \multicolumn{2}{c}{ Genotype } & Control & Case & $\chi^{2}$ & $P$ & Odds ratio (95\%CI) \\
GSTT1 & GSTP1 & & & & & \\
\hline Present & A/A & 45 & 34 & & \\
Present & with G & 14 & 21 & 3.86 & 0.28 & \\
Null & A/A & 31 & 38 & & & \\
Null & with G & 10 & 13 & & & \\
\hline Present & A / A & 45 & 34 & 3.64 & 0.056 & $1.73(0.98-3.05)$ \\
\hline
\end{tabular}

\section{GSTMI and NATI}

\begin{tabular}{ccccccc}
\hline \multicolumn{2}{c}{ Genotype } & Control & Case & $\chi^{2}$ & $P$ & Odds ratio (95\% CI) \\
GSTM1 & NAT1 & & & & \\
\hline Present & $* 4 / * 4$ & 22 & 14 & & \\
Present & with $* 10$ & 36 & 35 & \multirow{2}{*}{0.21} & \\
Null & $* 4 / * 4$ & 14 & 24 & 4.57 & & \\
Null & with $* 10$ & 28 & 32 & & & \\
\hline Present & $* 4 / * 4$ & 22 & 14 & \multirow{2}{*}{1.88} & 0.17 & $(0.78-4.15)$ \\
Null & with $* 10$ & 28 & 32 & & & (continue to the next page)
\end{tabular}




\section{GSTTl and NATI}

\begin{tabular}{|c|c|c|c|c|c|c|}
\hline \multicolumn{2}{|c|}{ Genotype } & \multirow[t]{2}{*}{ Control } & \multirow[t]{2}{*}{ Case } & \multirow[t]{2}{*}{$\chi^{2}$} & \multirow[t]{2}{*}{$P$} & \multirow[t]{2}{*}{ Odds ratio $(95 \% \mathrm{CI})$} \\
\hline GSTT1 & NAT1 & & & & & \\
\hline Present & $* 4 / * 4$ & 20 & 19 & \multirow{4}{*}{1.09} & \multirow{4}{*}{0.78} & \\
\hline Present & with $* 10$ & 39 & 36 & & & \\
\hline Null & $* 4 / * 4$ & 16 & 19 & & & \\
\hline Null & with $* 10$ & 25 & 32 & & & \\
\hline Present & $* 4 / * 4^{\dagger}$ & 20 & 19 & \multirow{2}{*}{0.51} & \multirow{2}{*}{0.47} & \multirow{2}{*}{$1.35(0.60-3.05)$} \\
\hline Null & with $* 10$ & 25 & 32 & & & \\
\hline \multicolumn{7}{|c|}{ GSTPl and NATI } \\
\hline \multicolumn{2}{|c|}{ Genotype } & Control & Case & $\chi^{2}$ & $P$ & Odds ratio $(95 \% \mathrm{CI})$ \\
\hline GSTP1 & NAT1 & & & & & \\
\hline $\mathrm{A} / \mathrm{A}$ & $* 4 / * 4$ & 27 & 27 & \multirow{4}{*}{1.88} & \multirow{4}{*}{0.60} & \\
\hline $\mathrm{A} / \mathrm{A}$ & with $* 10$ & 49 & 45 & & & \\
\hline with G & $* 4 / * 4$ & 9 & 11 & & & \\
\hline with $\mathrm{G}$ & with $* 10$ & 15 & 23 & & & \\
\hline \multirow{2}{*}{$\begin{array}{c}\mathrm{A} / \mathrm{A} \\
\text { with } \mathrm{G}\end{array}$} & $* 4 / * 4$ & 27 & 27 & \multirow{2}{*}{0.996} & \multirow{2}{*}{0.32} & \multirow{2}{*}{$1.53(0.66-3.55)$} \\
\hline & with $* 10$ & 15 & 23 & & & \\
\hline
\end{tabular}

(note : Affixed maker indicates reference group for odds ratio calculation.)

The $x^{2}$ value and significant level $P$ for each frequency table are depicted in the table. There was no statistically significant association between genotype and control-or-case. Even though the smallest $P$ value of chi-square tests was 0.120 for GSTM1, it was more than 0.05 , which is statistically meaningful.

Table 3 shows frequency tables of control and cases classified by the combination of genotype for two genes with the results of chi-square tests and odds ratio evaluation. Each table consists of $4 \times 2$ frequency tables. Besides this table, we made $2 \times 2$ frequency tables by proper grouping or extraction from genotype combinations.

Though there was no significant association for each $4 \times 2$ frequency table, $P$ value of chi-square tests for the genotype combination of GSTM1 and GSTP1 was 0.0589. Because this was near to the meaningful value 0.05 , we made $2 \times 2$ frequency tables by proper grouping for genotype combinations to increase the statistical significance. One of the new groups is one which has both GSTM1 present and GSTP1 A/A and the other is one that has other combinations; GSTM1 present and GSTP1 with G, GSTM1 null and GSTP1 A/A, GSTM1 null and GSTP1 with G. For this $2 \times 2$ frequency table, $P$ value of chi-square tests was 0.0086 and odds ratio was 2.15 (confidence interval was $1.21-3.79$ ). This shows that there is a statistically significant association of genotype combination of GSTM1 and GSTP1 with colorectal cancer incidences.

For other frequency tables of different two gene combinations, we could not observe any 
Table 4. Frequency table of control and case classified by pack-years as amount of cigarettes smoked with $\chi^{2}$ value and odds ratio

\begin{tabular}{lccccc}
\hline Pack-years & Control & Case & $\chi^{2}$ & $P$ & Odds ratio (95\% CI) \\
\hline Non-smokers & 45 & 53 & & & \\
$0<$ pack-years $\leqq 15$ & 11 & 9 & & & \\
$15<$ pack-years $\leqq 30$ & 18 & 17 & 4.04 & 0.40 & \\
$30<$ pack-years $\leqq 45$ & 18 & 12 & & & \\
$45<$ pack-years & 8 & 15 & & & \\
\hline Non-smokers $^{\dagger}$ & 45 & 53 & 0.52 & 0.47 & $0.82(0.47-1.41)$ \\
Smokers & 55 & 53 & & & \\
\hline
\end{tabular}

(note : Affixed maker ${ }^{\dagger}$ indicates reference group for odds ratio calculation.)

significant association, though some $P$ values were small, that is, close to 0.05 , for example, $P=0.056$ for the $2 \times 2$ table of GSTT1 and GSTP1, and $P=0.08$ for the $2 \times 2$ table of GSTM1 and GSTT1.

Smoking and cancer risk : In order to analyze the relation between cigarette smoking and cancer risk, we made a frequency table of control and case numbers classified by the amount of cigarette smoking. The quantity of cigarettes smoked was classified by 15 pack-year intervals; pack-year $=0$ (non-smoker), $0<$ pack-years $\leqq 15,15<$ pack-years $\leqq 30,30<$ packyears $\leqq 45,45<$ pack-years. The unit of 1 pack-year means that the person continues to smoke for one year at the rate of 1 pack (20 cigarettes) a day. The zero pack-year means that a person does not smoke at all. Table 4 shows a $5 \times 2$ frequency table and is followed by a $2 \times 2$ frequency table classified by non-smoker (pack-year $=0$ ) and smoker (pack-years $>0)$.

Because the $P$ values of chi-square tests for $5 \times 2$ and $2 \times 2$ tables was 0.40 and 0.47 , there was no significant association between the amount of cigarettes smoked and cancer incidences.

To examine the relation between the genotype, amount of smoking and cancer risk, we made a frequency table of control and cases classified by pack-years and genotype for each gene. Table 5 shows these tables with $x^{2}$ value and significant level $P$ of chi-square tests. We must note that we omitted a frequency table for NAT2 from Table 5, because the number of NAT2 slow genotypes was too small to perform a valuable statistical analysis. For all genes, no significant association was found between genotype difference, amount of smoking and cancer incidence.

We did the same statistical analysis for the genotype combination of the two gene pair, GSTM1 and GSTP1, because there was significant association between genotype difference and cancer risk only for this pair, as shown in the previous section. Table 6 shows the frequency table for this gene pair. However, no significant association was found for this table. 
Table 5. Frequency table of control and case classified by pack-years as amount of cigarettes smoked and genotype with $\chi^{2}$ value for each gene

GSTMI

\begin{tabular}{lrrrrrr}
\hline Pack-years & \multicolumn{2}{c}{ Control } & & Case & $\chi^{2}$ & $P$ \\
GSTM1 genotype : & Present & Null & Present & Null & & \\
\hline Non-smokers & 28 & 17 & 26 & 27 & & \\
$0<$ pack-years $\leqq 15$ & 7 & 4 & 4 & 5 & & 0.75 \\
$15<$ pack-years $\leqq 30$ & 8 & 10 & 7 & 10 & 8.41 & (not reliable) \\
$30<$ pack-years $\leqq 45$ & 9 & 9 & 7 & 5 & 9 & 0.74 \\
$45<$ pack-years & 6 & 2 & 6 & 26 & \\
\hline Non-smokers & 28 & 17 & 26 & 27 & \\
Smokers & 30 & 25 & 24 & 29 & & \\
\hline
\end{tabular}

\section{GSTT1}

\begin{tabular}{|c|c|c|c|c|c|c|}
\hline \multirow{2}{*}{$\begin{array}{l}\text { Pack-years } \\
\text { GSTT1 genotype : }\end{array}$} & \multicolumn{2}{|c|}{ Control } & \multicolumn{2}{|c|}{ Case } & \multirow[t]{2}{*}{$\chi^{2}$} & \multirow[t]{2}{*}{$P$} \\
\hline & Present & Null & Present & Null & & \\
\hline Non-smokers & 29 & 16 & 26 & 27 & \multirow[b]{3}{*}{10.81} & \multirow[b]{3}{*}{0.55} \\
\hline $0<$ pack-years $\leqq 15$ & 8 & 3 & 7 & 2 & & \\
\hline $15<$ pack-years $\leqq 30$ & 8 & 10 & 8 & 9 & & \\
\hline $30<$ pack-years $\leqq 45$ & 11 & 7 & 6 & 6 & \multicolumn{2}{|c|}{ (not reliable) } \\
\hline $45<$ pack-years & 3 & 5 & 8 & 7 & & \\
\hline Non-smokers & 29 & 16 & 26 & 27 & \multirow{2}{*}{1.85} & \multirow{2}{*}{0.60} \\
\hline Smokers & 30 & 25 & 29 & 24 & & \\
\hline \multicolumn{7}{|l|}{ GSTPI } \\
\hline Pack-years & \multicolumn{2}{|c|}{ Control } & \multicolumn{2}{|c|}{ Case } & $\chi^{2}$ & $P$ \\
\hline GSTP1 genotype : & $\mathrm{A} / \mathrm{A}$ & with $\mathrm{G}$ & $\mathrm{A} / \mathrm{A}$ & with $\mathrm{G}$ & & \\
\hline Non-smokers & 34 & 11 & 37 & 16 & & \\
\hline $0<$ pack-years $\leqq 15$ & 9 & 2 & 5 & 4 & & \\
\hline $15<$ pack-years $\leqq 30$ & 15 & 3 & 13 & 4 & 8.59 & 0.74 \\
\hline $30<$ pack-years $\leqq 45$ & 14 & 4 & 7 & 5 & \multirow{2}{*}{\multicolumn{2}{|c|}{ (not reliable) }} \\
\hline $45<$ pack-years & 4 & 4 & 10 & 5 & & \\
\hline Non-smokers & 34 & 11 & 37 & 16 & \multirow{2}{*}{0.70} & \multirow{2}{*}{0.87} \\
\hline Smokers & 42 & 13 & 35 & 18 & & \\
\hline \multicolumn{7}{|l|}{ NAT1 } \\
\hline Pack-years & \multicolumn{2}{|c|}{ Control } & \multicolumn{2}{|c|}{ Case } & $\chi^{2}$ & $P$ \\
\hline NAT1 genotype : & $* 4 / * 4$ & with $* 10$ & $* 4 / * 4$ & with $* 10$ & & \\
\hline Non-smokers & 17 & 28 & 18 & 35 & & \\
\hline $0<$ pack-years $\leqq 15$ & 4 & 7 & 4 & 5 & & \\
\hline $15<$ pack-years $\leqq 30$ & 4 & 14 & 6 & 11 & 14.61 & 0.26 \\
\hline $30<$ pack-years $\leqq 45$ & 4 & 14 & 4 & 8 & \multirow{2}{*}{\multicolumn{2}{|c|}{ (not reliable) }} \\
\hline $45<$ pack-years & 7 & 1 & 6 & 9 & & \\
\hline Non-smokers & 17 & 28 & 18 & 35 & \multirow{2}{*}{0.86} & \multirow{2}{*}{0.84} \\
\hline Smokers & 19 & 36 & 18 & 33 & & \\
\hline
\end{tabular}


Table 6. Frequency table of control and case classified by pack-years as amount of cigarettes smoked and genotype combination for GSTM1 and GSTP1 with $\chi^{2}$ value

GSTMI and GSTPI

\begin{tabular}{lrrrrrr}
\hline Pack-years & \multicolumn{2}{c}{ Control } & \multicolumn{2}{c}{ Case } & $\chi^{2}$ & $P$ \\
GSTM1 -P1 : & Present -A/A & Others & Present -A/A & Others & & \\
\hline Non-smokers & 24 & 21 & 16 & 37 & & \\
$0<$ pack-years $\leqq 15$ & 5 & 6 & 1 & 8 & & 0.86 \\
$15<$ pack-years $\leqq 30$ & 8 & 10 & 5 & 12 & 6.98 & (not reliable) \\
$30<$ pack-years $\leqq 45$ & 7 & 11 & 4 & 8 & 11 & \\
$45<$ pack-years & 3 & 5 & 4 & 37 & 2.01 & 0.57 \\
\hline Non-smokers & 24 & 21 & 16 & 39 & \\
\hline
\end{tabular}

\section{Discussion}

Genotypes and cancer risk : As shown in the previous section, we could not observe any significant association between genotype difference and colorectal cancer risk when examining any single gene, while there was statistically significant association for a genotype combination of two genes, that is, the colorectal cancer risk for a person who does not have GSTM1 present gene or GSTP1 A/A gene or either of them was significantly higher than for a person who has both GSTM1 present gene and GSTP1 A/A gene. It has been reported that both GSTM1 and GSTP1 genes seem to play a role in detoxification of benzo[a] pyrene $[22,23]$. The result suggested the possibility that the detoxification is the most effective when both GSTM1 present gene and GSTP1 A/A gene exist, while the effectiveness decreases when one or two of them are lacking. These isozymes may contribute to detoxify putative carcinogens in the colon of humans.

Several studies have tried to examine the relation between gene polymorphisms and the risk of colorectal cancer [27-32]. Strange et al . [27] and Zhong et al . [28] studied colorectal cancer risk using the GSTM1 gene and reported the association of GSTM1 null with colorectal cancer. But Chenevix-Trench et al . [29] and Gertig et al . [31] reported opposite results, that is, there was no association between GSTM1 genotype difference and the incidence of colorectal cancer. There were a few reports other than those regarding the GSTM1 gene. Gertig et al . [31] and Slattery et al . [32] studied using GSTT1 and NAT2 gene respectively, but found no association of genotype difference with cancer risk. In our study, we expanded the number of genes to treat and performed a statistical analysis of colorectal cancer risk not only for each single gene but also for any two gene pairs. Regarding the analysis for a single gene, there was no significant association of genotype difference with 
cancer risk. This supports the results by both Chenevix-Trench et al. [29] and Gertig et al . [31] and does not support results by both Strange et al . [27] and Zhong et al . [28] for GSTM1 .

Regarding the analysis for any two gene pairs, we observed a significant association for GSTM1 and GSTP1 pair. Deakin et al . [30] studied colorectal, lung, oral and gastric cancer risk using the same analysis method for the GSTM1 and GSTT1 pair. They reported a significant association of GSTM1 present and GSTT1 null pair with colorectal cancer. Though our result for the same pair does not support Deakin's as shown in Table 3, the $P$ values of chi-square tests for the $2 \times 2$ frequency table consisted of GSTM1 present and GSTT1 present pair class and GSTM1 null and GSTT1 null pair class is 0.08 , which is close to 0.05 . As this value is not negligible, we should continue to investigate the genotype combination of GSTM1 and GSTT1 pair in cancer risk research. Slattery et al . [32] studied colon cancer risk for the genotype combination of GSTM1 and NAT2 pair and reported no significant association. Our finding regarding the association of genotype combination of GSTM1 and GSTP1 pair with colorectal cancer risk has not been reported previously.

This means that a study for genotype combination of two or more than two genes is important.

Smoking and cancer risk : In our study, there was no significant association between the amount of cigarettes smoked and cancer incidences as discussed before and shown in Table 4. Some epidemiological studies have focused on the relation between cigarette smoking and the incidence of colorectal cancer or adenoma, which is considered as a precursor of cancer [24-26]. Giovannucci et al . [24] studied the effect of cigarette smoking amount on the incidence of colorectal cancer and adenoma, and reported a significant effect. Martinez et al . [25] also reported that cigarette smoking increases colorectal adenoma and Slattery observed a significant association of the amount of cigarettes smoked with increased risk of colon cancer. However, no significant association between cigarette smoking and colorectal cancer was found by Baron et al. [26].

A few studies tried to investigate the interaction between genotypes, smoking amount and colorectal cancer risk. Slattery et al. [32] reported no significant interaction between the genotype difference of GSTM1 and NAT2, cigarette smoking and colon cancer risk. Our study also did not find any significant association between these three factors. Though our result coincides with Slattery's, this does not mean that we may abandon the investigation of these interactions. A study using a large number of samples should be performed.

In our study, we collected only smoking amount data as an environmental factor. Some studies suggest the importance of food or nutrition factor in the incidence of colorectal cancer or adenoma $[25,26,34,35]$. Giovannucci et al . [35] reported that alcohol intake and low methionine or folate intake increase colon cancer risk. Martinez et al. [25] also reported that alcohol consumption increases colorectal adenomatous polyps. Baron et al .

[26] presented the same results, that is, the folate intake prevents colorectal adenoma and 
alcohol intake increases colorectal adenoma. These reports suggest the need of further study in which the diet pattern data of participants is included.

\section{References}

1. Ames BN, Durston AWE, Yamasaki E \& Lee FD (1973) : Carcinogens are mutagens, a simple test system combining liver homogenates for activation and bacteria for detection. Proc Natl Acad Sci USA $70: 2281-2285$

2. Miller EC (1978) : Some current perspectives on chemical carcinogenesis in humans and experimental animals. Cancer Res 38: 1479-1496

3 . Caporaso N, Landi MT \& Vineis P (1991) : Relevance of metabolic polymorphisms to human carcinogenesis : evaluation of epidemiologic evidence. Pharmacogenetics 1: 4-19

4 . Idle JR, Armstrong M, Boddy AV et al (1992) : The pharmacogenetics of chemical carcinogenesis. Pharmacogenetics 2: 246-258

5 . Roots I, Drakoulis N \& Brockmoller J (1992) : Polymorphic enzymes and cancer risk; concepts, methodology and data review. In : Pharmacogenetics of Drug Metabolism. (Kalow W, ed). Pergamon Press, New York pp 815-841

6. Seidegard J, Vorachek WR, Pero RW \& Pearson WR (1988) : Hereditary differences in the expression of the human glutathione transferase active on trans-stilbene oxide are due to a gene deletion. Proc Natl Acad Sci USA 85: 7293-7297

7 . Pemble S, Schroeder KR, Spencer SR, Meyer DJ, Hallier E, Bolt HM, Ketterer B \& Taylor JB (1994): Human glutathione S-transferase $\theta$ (GSTT1) : cDNA cloning and the characterization of a genetic polymorphism. Biochem J 300: 271-276

8 . Ali-Osman F, Akande O, Antoun G, Mao JX \& Buolamwini J(1997) : Molecular cloning, characterization, and expression in Escherichia coli of full-length cDNAs of three human glutathione Stransferase Pi gene variants. J Biol Chem 272: 10004-10012

9 . Bell DA, Stephens EA, Castranio T, Umbach DM, Watson M, Deakin M, Elder J, Hedrickse C, Duncan H \& Strange RC (1995) : Polyadenylation polymoephism in the acetyltransferase 1 gene (NAT1) increases risk of colorectal cancer. Cancer Res 55: 3537-3542

10. Degushi T, Mashimo M \& Suzuki T (1990) : Correlation between acetylator phenotypes and genotypes of polymorphic arylamine $\mathrm{N}$-acetyltransferase in human liver. J Biol Chem $265: 12757-$ 12760

11. Mannervik B, Alin P, Guthenberg C, Jensson H, Tahir MK, Warholm M \& Jornvall H (1985) : Identification of three classes of cytosolic glutathione transferase common to several mammalian species : correlation between structural data and enzymatic properties. Proc Natl Acad Sci USA 82: 72027206

12. Sies H \& Ketterer B (ed ) (1988) : Glutathione : mechanisms and significance. CRC Critical Reviews in Biochemistry and Molecular Biology. Academic Press, London

13. Ketterer B, Harris JM, Talaska G et al (1992) : The human glutathione S-transferase supergene fam- 
ily, its polymorphism, and its effects on susceptibility to lung cancer. Environ Health Perspect 98 : $87-94$

14. Guengerich FP, Thier R, Persmark M, Taylor JB, Pemble SE \& Ketterer B (1995)： Conjugation of carcinogens by $\theta$ class glutathione S-transferase : mechanisms and relevance to variations in human risk. Pharmacogenetics 5(Spec): S103-107

15. Watson MA, Stewart RK, Smith GBJ, Massey TE \& Bell DA (1998) : Human glutathione Stransferase P1 polymorphisms : relationship to lung tissue enzyme activity and population frequency distribution. Carcinogenesis 19: 275-280

16. Terrier P, Townsend AJ, Coindre JM, Triche TJ \& Cowan KH (1990) : An immunohistochemical study of pi class glutathione S-transferase expression in normal human tissue. Am J Pathol 137 : $845-853$

17. Cartwright RA, Glashan RW, Rogers HJ, Ahmad RA, Barham-Hall D, Higgins E \& Kahn MA (1982): Role of $N$-acetyltransferase phenotypes in bladder carcinogenesis : a pharmacogenetic epidemiological approach to bladder cancer. Lancet 8303: 842-845

18. Taylor JA, Umbach DM, Stephens E, Castranio T, Paulson D, Robertson C, Mohler JL \& Bell DA (1998) : The role of $N$-acetylation polymorphisms in smoking-associated bladder cancer : evidence of a gene-gene-exposure three-way interaction. Cancer Res 58: 3603-3610

19. Katoh T, Kaneko S, Boissy R, Watson M, Ikemura K \& Bell DA (1998) : A pilot study testing the association between $N$-acetyltransferase 1 and 2 and risk of oral squamous cell carcinoma in Japanese people. Carcinogenesis 19: 1803-1807

20. Edmund L, Yan H, Bin Z et al (1998）: Genetic polymorphism of conjugating enzymes and cancer risk : GSTM1, GSTT1, NAT1and NAT2. J Toxicol Sci 23(Sup 2) : 140-142

21. Hirayama T (1992) : Life style and cancer : from epidemiological evidence to public behavior change to mortality reduction of target cancers. J Natl Cancer Inst Monogr 12: 65-74

22. Hayes JD \& Pulford DJ (1995) : The glutathione S-transferase supergene family : regulation of GST and the contribution of the isoenzymes to cancer chemoprotection and drug resistance. Crit Rev Biochem Mol Biol 30: 445-461

23. Ozawa S (1997): Genetic polymorphisms in xenobiotic metabolizing enzymes as a determinant of susceptibility to environmental mutagens and carcinogens in humans. Yakugaku Zasshi 117 : 895-909 (in Japanese)

24. Giovannucci E, Rmm EB, Stampfer MJ, Colditz GA, Ascherio A, Kearney J \& Willett WC (1994) : A prospective study of cigarette smoking and risk of colorectal adenoma and colorectal cancer in U. S. men. J Natl Cancer Inst 86 : 183-191

25. Martinez ME, McPherson RS, Annegers JF \& Levin B (1995) : Cigarette smoking and alcohol consumption as risk factors for colorectal adenomatous polyps. J Natl Cancer Inst 87 : 274-279

26. Baron JA, Sandler RS, Haile RW, Mandel JS, Mott LA \& Greenberg ER (1998)： Folate intake, alcohol consumption, cigarette smoking, and risk of colorectal adenomas. J Natl Cancer Inst 90 : $57-62$

27. Strange RC, Matharoo B, Faulder GC, Jones P, Cotton W, Elder JB \& Deakin M (1991) : The hu- 
man glutathione S-transferases : a case-control study of the incidence of the GST1 0 phenotype in patients with adenocarcinoma. Carcinogenesis $12: 25-28$

28. Zhong S, Wyllie AH, Barnes D, Wolf CR \& Spurr NK (1993) : Relationship between the GSTM1 genetic polymorphism and susceptibility to bladder, breast and colon cancer. Carcinogenesis 14 : $1821-1824$

29. Chenevix-Trench G, Young J, Coggan M \& Board P (1995)：Glutathione S-transferase M1 and T1 polymorphisms : susceptiblility to colon cancer and age of onset. Carcinogenesis $16: 1655-$ 1657

30. Deakin M, Elder J, Hendricks C et al (1996) : Glutathione S-transferase GSTT1 genotypes and susceptibility to cancer : studies of interactions with GSTM1 in lung, oral, gastric and colorectal cancers. Carcinogenesis 17: $881-884$

31. Gertig DM, Stampfer M, Haiman C, Hennekens CH, Kelsey K \& Hunter DJ (1998)：Glutathione Stransferase GSTM1 and GSTT1 polymorphisms and colorectal cancer risk : a prospective study. Cancer Epidemiol Biomarkers Prev 7: 1001-1005

32. Slattery ML, Potter JD, Samowitz W, Bigler J, Caan B \& Leppert M (1998)： NAT2, GSTM-1, cigarette smoking, and risk of colon cancer. Cancer Epidemiol Biomarkers Prev 7: 1079-1084

33. Chen H, Sandler DP, Taylor JA, Shore DL, Liu E, Bloomfield CD \& Bell DA (1996) : Increased risk for myelodysplastic syndromes in individuals with glutathione transferase theta 1 (GSTT1) gene defect. Lancet 347 : 295-297

34. World Cancer Research Fund \& American Institute for Cancer Research (1997) : Food, nutrition and the prevention of cancer : a global perspective. American Institute for Cancer Research, Washington D.C. $670 \mathrm{pp}$

35. Giovannucci E, Rmm EB, Ascherio A, Stampfer MJ, Colditz GA \& Willett WC (1995): Alcohol, low-methionine-low-folate diets, and risk of colon cancer in men. J Natl Cancer Inst $87: 265-$ 273 
遺伝子多型と結腸直腸癌の発癌感授性

吉岡 真 ${ }^{1}$, 加藤 貴彦 ${ }^{1}$, 中野 正博 ${ }^{1}$, 高澤 信 ${ }^{2}$, 永田 直幹 ${ }^{2}$, 伊藤 英明 ${ }^{2}$

産業医科大学産業保健学部 保健情報科学講座

産業医科大学医学部 第一外科学教室

要＼cjkstart旨：結腸直腸癌について，発癌リスクと遺伝子変異，および揳煙の関係を調べるために 症例対照研究を行った。結腸直腸癌患者 106 名, 癌病歴のない対照群 100 名から採 取した血液検体に対し, 5 種の遺伝子（GSTM1, GSTT1,GSTP1, NAT1,NAT2）につい て，PCR法による遺伝子型の同定を行い，アンケート調查により各被験者の喫煙量に ついて調べた。各遗伝子について個別に遺伝子型と癌の発症との関連性の検定を行 ったが，遺伝子型の違いと発癌リスクの間に有意な関連は見出せなかった．次に，

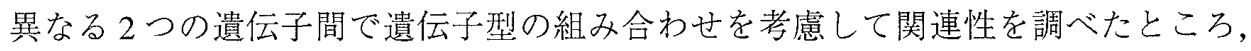
GSTM1 present型とGSTP1 Adenine/Adenine型（313 番目ヌクレオチド）の両者を持 つ者がそれ以外の組み合わせの遺伝子型を持つ者に比べ有意に結腸直腸癌の発症率 が低くなることが示された．喫煙量と癌発生との関連については両者の間には有意 な関連は見られなかった。遺伝子型と喫煙量と癌発生の間の関連についても同様に 有意な関連はなかった。本研究の結果は，遺伝子型と癌発症の関連を調べる時，同 時に複数の遺伝子を考慮することの有用性を示すものとなった．今後，統計学的信 頼性を上げるために標本数を増やすと共に，環境要因として喫煙以外の因子，例え ば食事の内容等を含めた調査が必要と考えられる。

J UOEH（産業医大誌）21（2）：133-147（1999） 